\title{
Biosorption of Chromium (VI) in Aqueous Solution by Ananas comosus Biomass Shell
}

\author{
Acosta Rodríguez I늘 Cárdenas González JF ${ }^{2 *}$, Galaviz Orocio $\mathrm{K}^{1}$, Rodríguez \\ Pérez $\mathrm{A}^{2}$, Michel Cuello $\mathrm{C}^{2}$ and Muñoz Morales $\mathrm{A}^{2}$ \\ ${ }^{1}$ Facultad de Ciencias Químicas, México \\ ${ }^{2}$ Unidad Académica Multidisciplinaria Zona Media, México
}

ISSN: 2637-7659

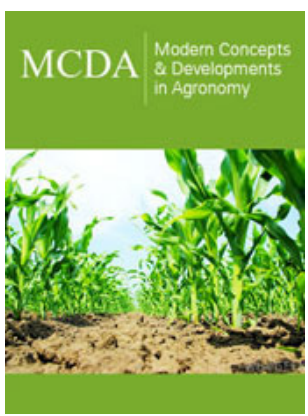

*Corresponding author: Cárdenas González JF, Unidad Académica Multidisciplinaria Zona Media, México

Submission: 非 April 28, 2019

Published: 監 May 10, 2019

Volume 4 - Issue 1

How to cite this article: Acosta $R$ I1, Cárdenas G JF2*, Galaviz 0 K1, Rodríguez P A2, Michel C C, et al Biosorption of Chromium (VI) in Aqueous Solution by Ananas comosus Biomass Shell. Mod Concep Dev Agrono.4(2). MCDA.000584.2019.

DOI: 10.31031/MCDA.2019.04.000584

Copyright@ Cárdenas González JF, This article is distributed under the terms of the Creative Commons Attribution 4.0 International License, which permits unrestricted use and redistribution provided that the original author and source are credited.

\begin{abstract}
Effluents from tanneries are one of the main sources of contamination with Chromium (VI) of water and soils. This metal is used in tanning leather and skins, steel alloys, electroplating, textile staining and as a biocide in water cooling systems in nuclear plants, discharging the metal to the environment representing a great risk to the health of living organisms, so in this work, we studied the Chromium (VI) removal in aqueous solution by the Ananas comosus biomass shell, by the Diphenylcarbazide method to evaluate the metal concentration in solution. Biosorption at different $\mathrm{pH}(1,2,3$ and 4$)$ was evaluate for different times. We too studied the effect of temperature in the range of 28 to $60{ }^{\circ} \mathrm{C}$ and the removal at different initial concentrations of Chromium (VI) of 200 to $1000 \mathrm{mg} / \mathrm{L}$. Therefore, the highest biosorption of the metal $(100 \mathrm{mg} / \mathrm{L})$ occurs within 10 hours, at $\mathrm{pH}$ of $1.0,28^{\circ} \mathrm{C}$ with $5 \mathrm{~g}$ of natural biomass. According to temperature, the highest removal was observing at $60^{\circ} \mathrm{C}$, in 3 hours, when the metal is completely adsorbed. At the analyzed concentrations of $\mathrm{Cr}(\mathrm{VI})$, fungal biomass, showed excellent removal capacity at $60^{\circ} \mathrm{C}$, it removal $1 \mathrm{~g} / \mathrm{L}$ of the metal in 45 minutes, besides it removal efficiently the metal in situ $(100 \%$ and $97.2 \%$ removal in $100 \mathrm{~mL}$ of water and $10 \mathrm{~g}$ of earth contaminated, after 9 and 10 days of incubation, with $10 \mathrm{~g}$ of biomass; so, it can be used to eliminate it from industrial wastewater.
\end{abstract}

Keywords: Biosorption; Chromium (VI); Pineapple; Biomass; Bioremediation

\section{Introduction}

Currently, one of the main environmental problems is heavy metal pollution. These elements alter the equilibrium of ecosystems by persisting indefinitely in the environment, because they are not degrading by biological or chemical means [1]. Its accumulation in the organisms of the different links of the trophic chain, its mobility in natural aquatic ecosystems and its toxicity, make its elimination a global concern [2]. The introduction and redistribution of metal ions in the biosphere have their origin from natural and anthropogenic sources [3]. However, the main direct as well as indirect cause of the metal contamination are the urban sources, being the industrial operations with a deficient or absent treatment of its residual waters and solid waste, its main emitter. Some of the industries that generate waste contaminated with these elements are sugar, oil, brewing, textiles, cellulose and paper, metal finishing, copper and its alloys, tannery, food and of iron and steel, legally classified as point sources of pollution [2]. Hexavalent chromium [Cr (VI)] is an important water pollutant. Even at metals levels measuring in the parts per billion (ppb), research has shown it to be toxic [4]. Cr (VI) can originate from different anthropogenic activities such as chromite mining, leather tanning, pigment synthesis, electroplating and metal finishing [4]. The primary forms of chromium found in nature are $\mathrm{Cr}$ (III) and $\mathrm{Cr}$ (VI) and these forms are converting to each other depending on environmental conditions [5]. $\mathrm{Cr}$ (VI) is consider the most toxic form of chromium and is usually associated with oxygen as chromates $\left(\mathrm{CrO}_{4}^{-2}\right)$ and dichromate $\left(\mathrm{Cr}_{2} \mathrm{O}_{7}\right.$ ${ }^{2}$ ) [4]. It has been established now that various chromium compounds as oxides, chromates and dichromate, are environmental contaminants in water, soil, and industrial effluents, because this metal is widely used in various manufacturing, such as electrolytic plating, explosives manufacturing, leather tanning, metal alloy, dyes and pigments manufacturing, etc., [2,3\&5].

There are studies of the current technologies that are being used to effectively reduce $\mathrm{Cr}$ (VI) present in aqueous solutions by means of chemical, electrochemical and biological methods, for example: ion exchange on resins, coagulation-flocculation, adsorption on 
activated carbon, reduction, chemical precipitation, sedimentation, etc., [6], which in most cases are expensive or inefficient, especially when the concentration of these ions is very low [7]. Therefore, arise emerging technologies such as biosorption, the process of attracting various chemical species by biomass (live or dead), by physicochemical mechanisms as adsorption or ion exchange [8]. Recently, varieties of low-cost materials have been study for their ability to remove Cr (VI) from aqueous solution and promising results are shown. Among these low-cost adsorbents are dead microorganisms, clay minerals, agricultural wastes, industrial wastes and various other low-cost materials [4,6-9]. Thus, there is a need to develop or find innovative low-cost adsorbents with an affinity towards metal ions for the removal of $\mathrm{Cr}$ (VI) from aqueous solution, which leads to high adsorption capacity [4,6-8]. The objective of this study was to analyze in vitro biosorption of $\mathrm{Cr}$ (VI) by pineapple (Ananas comosus) biomass shell.

\section{Material and Methods}

\section{Preparation of the bio sorbent}

The Ananas comosus shell, was obtained from the fruits harvested and offered in the market place Republic, between the months of July to August in 2017, of the capital city of San Luis Potosí, S.L.P. México. To obtain the biomass, the shells was washed with trideionized water during 72 hours at constant stirring, with water changes every 12 hours. Subsequently, it was boiling 1 hour to removal traces of the fruit and dust and were dry at $80^{\circ} \mathrm{C}$ for 12 hours in an oven, ground in blender and stored in amber vials until use.

\section{Biosorption studies and determination of hexavalent, trivalent and total $\mathrm{Cr}$}

For these studies, was used $5 \mathrm{~g}$ of dried biomass mixed with $100 \mathrm{~mL}$ of trideionized water containing $100 \mathrm{mg} / \mathrm{L}$ of the metal, in an Erlenmeyer flask at the desired temperature and $\mathrm{pH}$. The flasks were agitated on a shaking bath Yamato BT-25 model at different times. Samples of $5 \mathrm{~mL}$ were taken at different times and centrifuged at $3000 \mathrm{rpm}$ for $5 \mathrm{~min}$. The supernatant liquid was separated and analyzed for $\mathrm{Cr}$ (VI) ions. Hexavalent Chromium and trivalent Chromium were quantifying by a Spectrophotometric method employing Diphenylcarbazide and chromazurol S, respectively $[10,11]$, total Chromium was determining by electrothermal atomic absorption spectroscopy [11]. The information shown in the results section are the mean from three experiments carried out by triplicate.

\section{Results and Discussion}

\section{Effect of incubation time and $\mathrm{pH}$}

The optimum time and $\mathrm{pH}$ for $\mathrm{Cr}(\mathrm{VI})$ removal for pineapple biomass, was 10 hours and pH 1.0, at constant values of biosorbent dosage $(5 \mathrm{~g} / 100 \mathrm{~mL})$, with an initial metal concentration of $100 \mathrm{mg} / \mathrm{L}$, and a temperature of $28{ }^{\circ} \mathrm{C}$ (Figure 1). It was used a pH meter Corning Pinnacle 530 model and we use nitric acid $1 \mathrm{M}$ to maintain the $\mathrm{pH}$. The literature $[12,13]$, report an optimum time of 2 and 4 hours for the removal of $\mathrm{Cr}$ (VI) by Macadamia nutshell powder [12] and Amarantus caudatus [13], with 2.5g/L and $5 \mathrm{~g} / 100 \mathrm{~mL}$, of natural biomass respectively, 24 hours for the avocado shell, with $102 \mathrm{mg} / \mathrm{L}$ and $1 \mathrm{~g} / \mathrm{L}$ of Chromium (VI) [14], 5 minutes for almond green hull, with a concentration of $10 \mathrm{mg} / \mathrm{L}$ of the metal and $4 \mathrm{~g}$ of biomass [15], and 9 hours for sawdust of pine tree [16], with an initial metal concentration of 50mg/L. Changes in the cell permeability of unknown origin, could partly explain the differences founded in the incubation time, providing greater or lesser exposure of the functional groups of the cell wall of the biomass analyzed [1,3, 6-8]. Adsorption efficiency of Cr (VI) was observe a maximum at $\mathrm{pH} 1.0$ with the biomass analyzed, and this is like to most reports [1,13-16], but some report other $\mathrm{pH}^{\prime} \mathrm{s}$, like for avocado shell [14], and almond green hull [15], which report an optimum $\mathrm{pH}$ of 2.0. This was due to the dominant species $\left(\mathrm{CrO}_{4}{ }^{2-}\right.$ and $\mathrm{Cr}_{2} \mathrm{O}_{7}{ }^{2-}$ ) of $\mathrm{Cr}$ ions in solution, which were expected to interact more strongly with the ligands carrying positive charges $[1,7,8]$.

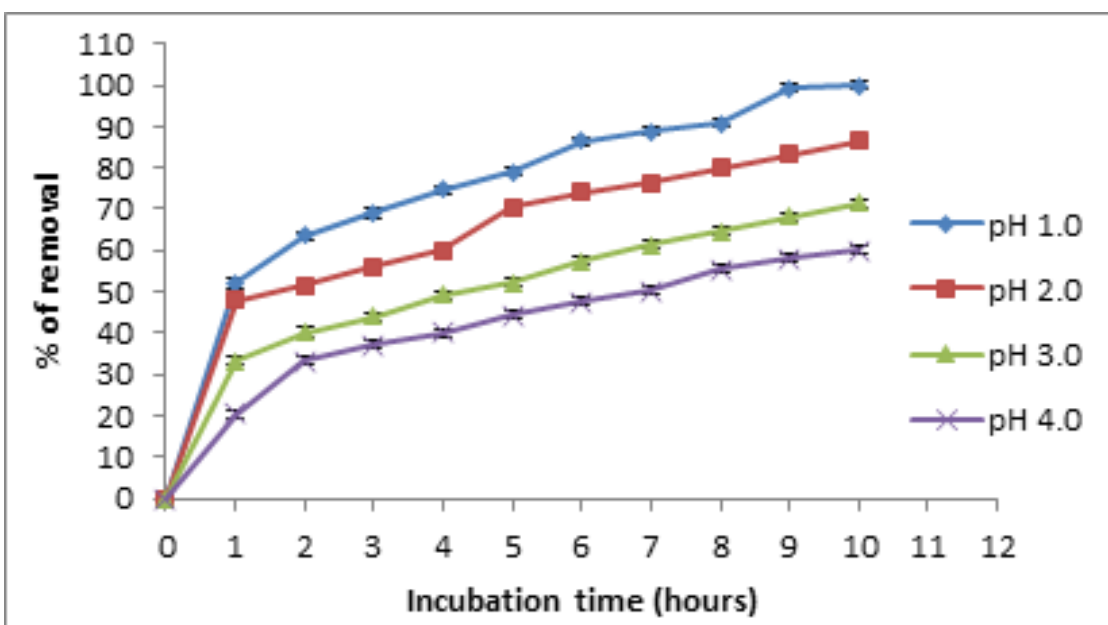

Figure 1: Effect of incubation time and $\mathrm{pH}$ on Chromium (VI) removal by the biomass of A. comosus shell. 100mg/L Cr (VI), $100 \mathrm{rpm}, 28^{\circ} \mathrm{C} .5 \mathrm{~g}$ of biomass. 


\section{Effect of the temperature}

Temperature was found to be a critical parameter in the bio adsorption of $\mathrm{Cr}$ (VI) (Figure 2). To maintain constant the temperature in all experiments, we use a shaking bath Yamato BT25 model. The total removal was observed at $60^{\circ} \mathrm{C}$ and $28^{\circ} \mathrm{C}$ with 3 hours and 24 hours of incubation. This results are coincident for tamarind shell with $95 \%$ of removal at $58{ }^{\circ} \mathrm{C}$ and 3 hours [16], for the adsorption of cadmium (II) from aqueous solution on natural and oxidized corncob $\left(40^{\circ} \mathrm{C}\right.$ and 5 days) [17], but these are different for the mandarin waste [18], Caladium bicolor (wild cocoyam) biomass [19], and Saccharomyces cerevisiae [20]. The increase in temperature increases the rate of removal of $\mathrm{Cr}(\mathrm{VI})$ and decrease the contact time required for complete removal of the metal, to increase the redox reaction rate [16].

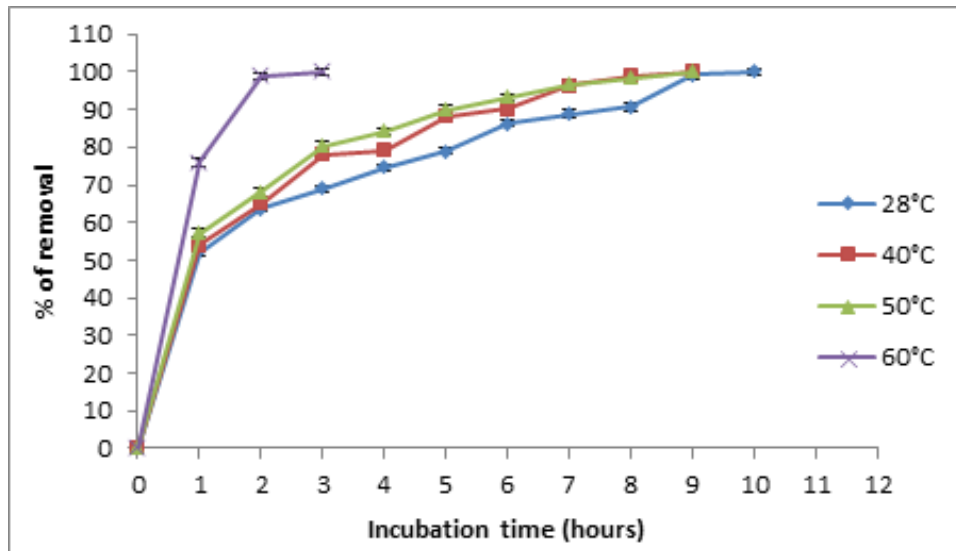

Figure 2: Effect of the temperature on Chromium (VI) removal by the biomass of A. comosus shell. 100mg/L Cr (VI), $100 \mathrm{rpm}, \mathrm{pH}$ 1.0. $5 \mathrm{~g}$ of biomass.

\section{Effect of the initial metal concentration}

At low metal concentrations $(200 \mathrm{mg} / \mathrm{L})$ a $28^{\circ} \mathrm{C}$, we observe the best results for removal, with the biomass analyzed, because the removal of the metal was $100 \%$ and $48 \%$, at 24 hours for 200 and $1000 \mathrm{mg} / \mathrm{L}$, respectively (Figure 3). The results are coincident for $A$ caudatus [13], with a total removal of the metal $(200 \mathrm{mg} / \mathrm{L})$ at 10 hours, for almond green hull with $50 \mathrm{mg} / \mathrm{L}$ of the metal and different amounts of sorbent $(13,15,18$ and $20 \mathrm{~g})$ at $\mathrm{pH}$ of 6.0 after 40 minutes of incubation [15], for modified Russian knapweed flower powder with increasing initial concentration of $\mathrm{Cr}$ (VI) solution from 2 to $20 \mathrm{mg} / \mathrm{L}$, chromium removal reduced, with a removal efficiency for 2 and $20 \mathrm{mg} / \mathrm{L}$ were $99.85 \%$ and $39.41 \%$, respectively [21], and in Vetiveria zizanioides, varying the concentration of $\mathrm{Cr}$ (VI) from 1 to $5 \mathrm{mg} / \mathrm{L}$ in synthetic solution, $\mathrm{pH} 1.0$, with stirring rate of $150 \mathrm{rpm}$ at room temperature and contact time of 4 and $5 \mathrm{~h}$ for grass and roots, respectively. It can be concluded from that removal efficiency decreases with increase in initial concentration of $\mathrm{Cr}$ (VI) in synthetic solution [22]. This was due to the increase in the number of ions competing for the available functional groups on the surface of biomass [1,4]. On the other hand, at $60{ }^{\circ} \mathrm{C}$, the biomass studied, shows the same results for removal, adsorbing $100 \%$ between 30 and 35 minutes with 200 and $1000 \mathrm{mg} / \mathrm{L}$ of metal, respectively (Figure 4) with respect to other biomasses, this results are like for Penicillium sp., IA-01 [23], but there are other studies, which report a major biosorption with low concentrations: Citrus reticulata and Tamarindus indica shell $[24,16]$. In addition, we observe the development of a blue-green and white precipitate, which changes more rapidly at higher temperatures (date not shown).



Figure 3: Effect of the initial concentration of the metal on Chromium (VI) removal by the biomass of A. comosus shell. 100rpm, pH 1.0. $5 \mathrm{~g}$ of biomass. $28^{\circ} \mathrm{C}$. 


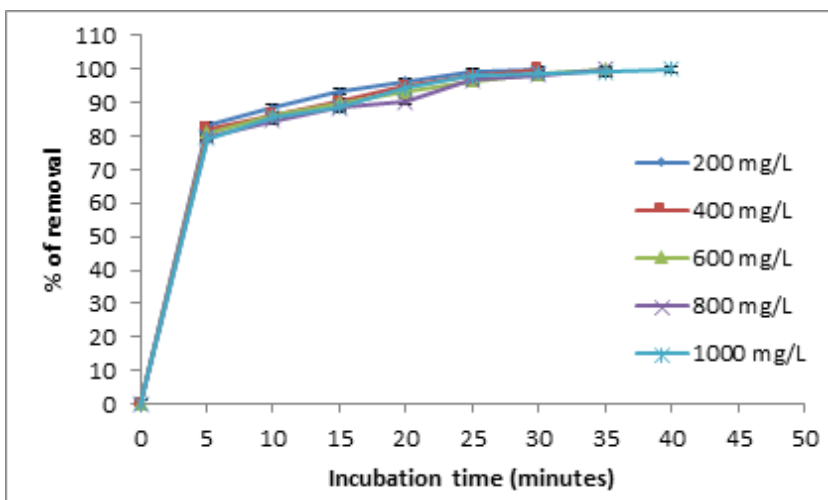

Figure 4: Effect of the initial concentration of the metal on Chromium (VI) removal by the biomass of A. comosus shell. $100 \mathrm{rpm}, \mathrm{pH} 1.0 \mathrm{~g}$ of biomass. $60^{\circ} \mathrm{C}$.

\section{Effect of the biosorbent dose}

The influence of biomass concentration on the removal capacity of $\mathrm{Cr}$ (VI) is depict in Figure 5. If we increase, the amount of biomass also increases the removal of the metal in solution, with more biosorption sites of the same, because the amount of added biosorbent determines the number of binding sites available for metal biosorption [25-27]. For Almond green hull, with a concentration of $10 \mathrm{mg} / \mathrm{L}$ of the metal with $0.5,1,1.5,2,2.5,3,3.5$ $4,4.5$, and $5 \mathrm{~g}$ of biomass [15]. Too, the removal efficiency using oleaster (Elaeagnus) seed and cherry (Prunus avium) stone biochar, increased with the increase of the biochar mass for a certain $\mathrm{Cr}(\mathrm{VI})$ concentration [22], for modified Russian knapweed flower powder at the initial chromium concentrations of 2,10 and $15 \mathrm{mg} / \mathrm{L}$ at $\mathrm{pH}$ 2 , and the results showed that chromium removal at an equilibrium condition increased with increasing adsorbent dose [22].

Figure 5: Effect of biomass concentration of A. comosus on the removal of $100 \mathrm{mg} / \mathrm{L} \mathrm{Cr}(\mathrm{VI}), 28{ }^{\circ} \mathrm{C}, \mathrm{pH} 1.0,100 \mathrm{rpm}$.

\section{Time course of Chromium (VI) decrease and Chromium} (III) production

We analyzed the ability of $A$. comosus biomass to reduce $1.0 \mathrm{~g} / \mathrm{L}$ of $\mathrm{Cr}$ (VI) and $\mathrm{Cr}$ (III) production in solution. The biomass exhibited a great efficiency to diminish metal level with the concomitant production of $\mathrm{Cr}$ (III) in the solution, as at 90min of incubation, we observe a drop in metal initial concentration to almost undetectable levels, without change significant in total Chromium concentration, which remained constant over time, in solution control, probably due to the vitamin C content in the shell (Figure 6) [28].

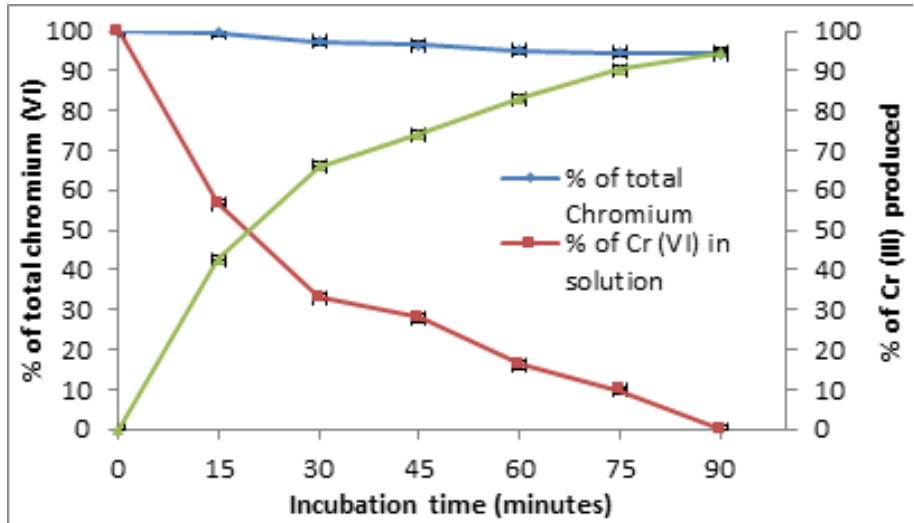

Figure 6: Time-course of $\mathrm{Cr}$ (VI) decrease and $\mathrm{Cr}$ (III) production in solution with $1.0 \mathrm{~g} / \mathrm{L} \mathrm{Cr}$ (VI). $28{ }^{\circ} \mathrm{C}, \mathrm{pH} 1.0,100 \mathrm{rpm}$. 


\section{Removal of Chromium (VI) in industrial wastes with A. comosus biomass}

Finally, we analyzed the possible usefulness of this biomass for removal this metal from industrial wastes. The biomass (5g) was incubate with non-sterilized contaminated earth and water containing $100 \mathrm{mg} \mathrm{Cr}(\mathrm{VI}) / \mathrm{g}$, resuspended in trideionized water to a final volume of $100 \mathrm{~mL}$. It was observing that in 9 and 10 days of incubation, the Cr (VI) concentration of water and earth samples, decrease fully in water and $97.2 \%$ in earth (Figure 7), without change significant in total Chromium content during the experiments. In the experiment control (without biomass), the metal concentration of the water and earth samples decreased by about of $6 \%$ and $18 \%$ (date not shown); which can be caused by indigenous microflora and (or) reducing components present in the samples [1,4,8\&29]. The chromium removal abilities of this biomass are equal or better than other biomasses reported, for example A. caudatus [13], Melaleuca diosmifolia leaf [28], T. indica, M. paradisiaca, C. limonium, and C. sinensis shells [30], maize leaf [31], C. melo shell [9], sawdust of pine tree [16], M. indica, $M$. paradisiaca, C. paradise, C. melo y C. máxima shells [24].



Figure 7: Removal of $\mathrm{Cr}$ (VI) in industrial wastes incubated with $5 \mathrm{~g}$ of A. comosus biomass. $28^{\circ} \mathrm{C}, 100 \mathrm{rpm}, 100 \mathrm{~mL}$ of contaminated earth and water, (100mg Cr (VI)/g earth and $100 \mathrm{mg} / \mathrm{L}$ of water) (adjusted).

\section{Conclusion}

In this work, the biomass analyzed, showed complete capacity of biosorption of $100 \mathrm{mg} / \mathrm{L}$ of $\mathrm{Cr}$ (VI) in solution at 10 hours at $\mathrm{pH} 1.0$ with $5 \mathrm{~g}$ of natural biomass, and at $60^{\circ} \mathrm{C}$, in 3 hours the metal was fully adsorbed, besides this biomass, removal the metal in wastewater with 5 of biomass in water and earth (both with $100 \mathrm{mg} / \mathrm{g}$ of earth, and $100 \mathrm{mg} / \mathrm{L}$ of water) decrease $100 \%$ and $97.2 \%$, respectively. These results suggest the potential applicability of this natural biomass for the remediation of $\mathrm{Cr}$ (VI) from polluted water and earth.

\section{Acknowledgement}

All the authors are grateful for the cooperation of the Research and Linking Center "El Balandran", which is an extension of the Multidisciplinary Academic Unit of the UASLP, for the elaboration of some experiments in its facilities. In the same way the authors thank the Faculty of Chemical Sciences of the UASLP for the use of their facilities for the elaboration of some experiments. The authors declare that there is no conflict of interest and that the project was not financed by any instance, it was carried out with their own means.

\section{References}

1. Ahemad M (2014) Bacterial mechanisms for Cr (VI) resistance and reduction: an overview and recent advances. Folia Microbiologica 59(4): 321-332.

2. Chowdhury S, Jafar MA, Al Atta O, Husain T (2016) Heavy metals in drinking water: Occurrences, implications and future needs in developing countries. Sci Total Environ 569-570: 476-488.

3. Pérez Bou L, Salgado Bernal I, Larrea Duarte C, Martínez Sardiñas A, Cruz Arias ME, et al. (2018) Biosorción microbiana de metales pesados: características del proceso. Revista Cubana de Ciencias Biologicas 6(1): $1-12$.

4. Pradhan D, Sukla LB, Sawyer M, Rahman PK (2017) Recent bioreduction of hexavalent chromium in wastewater treatment: A review. Journal Industrial and Engineering Chemistry 55: 1-20.

5. https://www.epa.gov/

6. Barrera Díaz CE, Lugo Lugo V, Bilyeu B (2012) A review of chemical, electrochemical and biological methods for aqueous $\mathrm{Cr}$ (VI) reduction. J Hazard Mater 223-224: 1- 12.

7. Tejada Tovar C, Villabona Ortiz A, Garcés Jaraba L (2015) Adsorción de metales pesados en aguas residuales usando materiales de origen biológico. Tecno Lógicas 18(34): 109-123.

8. Gutiérrez Corona JF, Romo Rodríguez P, Santos Escobar F, Espino Saldaña AE, Hernández Escoto H (2016) Microbial interactions with chromium: basic biological process and applications in environmental biotechnology. World J Microbiol Biotechnol 32(12): 191.

9. Acosta Rodríguez I, Cárdenas González JF, Moctezuma Zárate MG, Martínez Juárez VM (2013) Removal of hexavalent chromium from solutions and contaminated sites by different natural biomasses. In: Applied bioremediation-active and passive approaches. Yogesh B Patil and Prakash Rao (Eds.), INTECH, Croatia, pp. 207-224.

10. Greenberg AE, Clesceri LS, Eaton AD (1992) Standard methods for the examination of water and wastewater. American Public Health Association, (18 ${ }^{\text {th }}$ edn), Washington, USA.

11. Pantaler RP, Pulyaeva IV (1985) A spectrophotometric study of complexation between chromium and chromazurol S. Journal of Analytical Chemistry 40: 1634-1639.

12. Londolani C, Maremeni C, Modise SJ, Mtunzi FM, Klink MJ et al. (2018) Adsorptive removal of hexavalent Chromium by Diphenylcarbazidegrafted Macadamia nutshell powder. Bioinorganic Chemistry and Applications p. 14.

13. Rodríguez A, Pacheco NC, Cárdenas JF, Tovar J, Martínez VM, et al. (2017) Bioadsorción de Cromo (VI) en solución acuosa por la biomasa 
de Amaranto (Amaranthus caudatus). Avances en Ciencias e Ingeniería 8(2): 11-20.

14. Netzahuatl Muñoz AR, Pineda Camacho G, Barragán Huerta BE, Cristiani Urbina E (2010) Evaluación de la cascara de aguacate para la remoción de cromo hexavalente y cromo total de soluciones acuosas. Revista CENIC 41(4): 1-10.

15. Sahranavard M, Ahmadpour A, Reza Doosti M (2011) Biosorption of hexavalent Chromium ions from aqueous solutions using Almond green hull as a low-cost biosorbent. European Journal of Scientific Research 58(3): 392-400.

16. Acosta Rodríguez I, Ruíz Trujillo KC, Cárdenas González JF, Moctezuma Zárate MG, Martínez Juárez VM (2015) Chromium (VI) removal by Sawdust of pine tree. International Journal of Latest Research in Science and Technology 4(2): 124-128.

17. Agarwal GS, Kumar H, Chaudari S (2006) Biosorption of aqueous chromium (VI) by Tamarindus indica seeds. Bioresour Technol 97(7): 949-956.

18. Leyva R, Bernal LA, Acosta I (2005) Adsorption of cadmium (II) from aqueous solution on natural and oxidized corncob. Separation and Purification Technology 45(1): 41-49.

19. Zubair A, Bhatti HN, Hanif MA, Shafqat F (2008) Kinetic and equilibrium modeling for $\operatorname{Cr}(\mathrm{III})$ and $\mathrm{Cr}(\mathrm{VI})$ removal from aqueous solutions by Citrus reticulate waste biomass. Water, Air, Soil and Pollution 191(1-4): 305-318.

20. Michael Horsfall Jnr, Spiff AI (2005) Effects of temperature on the sorption of $\mathrm{Pb} 2+$ and $\mathrm{Cd} 2+$ from aqueous solution by Caladium bicolor (wild cocoyam) biomass. Electronical Journal of Biotechnology 8(2): 162-169.

21. Ozer A, Ozer D (2003) Comparative study of the biosorption of Pb (II), $\mathrm{Ni}$ (II) and Cr (VI) ions onto Saccharomyces cerevisiae: Determination of biosorption heats. J Hazard Mater 100(1-3): 219-229.

22. Ghaneian MT, Dehvari M, Jamshidi B (2013) A batch study of hexavalent chromium removal from synthetic wastewater using modified Russian knapweed flower powder. International Journal of Environmental Health Engineering 2(5): 38-46.
23. Tyagi U, Khandegar V (2018) Biosorption potential of Vetiveria zizanioides for the removal of Chromium (VI) from synthetic wastewater. Journal of Hazarous Toxic Radioactive Waste 22(4).

24. Acosta Rodríguez I, Arévalo Rangel DL, Cárdenas González JF, Moctezuma Zárate MG, Martínez Juárez VM (2015) Hexavalent Chromium (VI) Removal by Penicillium sp. IA-01. In: Nafumi Shiomi (Ed.), Advances in Bioremediation of wastewater and polluted soil. INTECH, Croatia, pp. 165-198.

25. Acosta Rodríguez I, Cárdenas GonzálezJF, Torre Bouscoulet ME, González Estrada A, Guerrero Martínez SE, et al. (2015) Biosorption of chromium (VI) by different natural biomasses. Journal of Multidisciplinary Engineering Science and Technology 2(7): 1736-1741.

26. Kahraman HT, Pehlivan E (2017) Cr6+ removal using oleaster (Elaeagnus) seed and cherry (Prunus avium) stone biochar. Powder Technology 306: 61-67.

27. Rangabhashiyam S, Selvaraju N (2015) Adsorptive remediation of hexavalent chromium from synthetic wastewater by a natural and $\mathrm{ZnCl} 2$ activated Sterculia guttata shell. Journal of Molecular Liquids 207: 3949.

28. Kuppusamy S, Thavamanic P, Megharajb M, Venkateswarlue K, Bok Lee Y et al. (2016) Potential of Melaleuca diosmifolia leaf as a low-cost adsorbent for hexavalent chromium removal from contaminated water bodies. Process Safety and Environmental Protection 100: 173-182.

29. Volesky B, Holan ZR (1995) Biosorption of heavy metals. Biotechnol Prog 11(3): 235-250.

30. Kelly Vargas K, Cerro López M, Reyna Téllez S, Bandala ER, Sánchez Salas JL (2012) Biosorption of heavy metals in polluted water, using different waste fruit cortex. Physics and Chemistry of the Earth, Parts A/B/C 3739: 26-29.

31. Adesola NA, Oyebamiji J, Adebowale S (2006) Biosorption of lead ions from aqueous solution by maize leaf. International Journal of Physical Sciences 1(1): 23-26. 